\title{
Sequential Induction of Nodulin Gene Expression in the Developing Pea Nodule
}

\author{
Ben Scheres, ${ }^{a, 1}$ Fred van Engelen, ${ }^{a}$ Esther van der Knaap, ${ }^{a}$ Clemens van de Wiel, ${ }^{a, b}$ Ab van Kammen, ${ }^{a}$ \\ and Ton Bisseling, ${ }^{a, 2}$ \\ aDepartment of Molecular Biology, Agricultural University, Dreijenlaan 3, 6703 HA Wageningen, The Netherlands \\ 'Department of Plant Cytology and Morphology, Agricultural University, Arboretumlaan 4, \\ 6703 BD Wageningen, The Netherlands
}

\begin{abstract}
A set of cDNA clones have been characterized that represent early nodulin mRNAs from pea root nodules. By RNA transfer blot analyses, the different early nodulin mRNAs were found to vary in time course of appearance during the development of the indeterminate pea root nodule. In situ hybridization studies demonstrated that the transcripts were located in different zones, representing subsequent steps in development of the central tissue of the root nodule. ENOD 12 transcripts were present in every cell of the invasion zone, whereas ENOD5, ENOD3, and ENOD14 transcripts were restricted to the infected cells in successive but partially overlapping zones of the central tissue. We conclude that the corresponding nodulin genes are expressed at subsequent developmental stages. The amino acid sequence derived from the nucleotide sequences of the cDNAs, in combination with the localization data, showed that ENOD5 is an arabinogalactan-like protein involved in the infection process, whereas ENOD3 and ENOD14 have a cysteine cluster suggesting that these are metal-binding proteins. Furthermore, we showed that there is a clear difference in the way Rhizobium induced the infection-related early nodulin genes ENOD5 and ENOD12. A factor acting over a long distance induced the ENOD12 gene, whereas a factor acting over a short distance activated the ENOD5 gene.
\end{abstract}

\section{INTRODUCTION}

The formation of nodules on roots of leguminous plants induced by Rhizobium bacteria proceeds according to Vincent (1980) as a "multistage sequence of interdependent steps." Based on cytological examinations of nodule development and the observation that this development can be blocked at discrete stages using plant or Rhizobium mutants, root nodule formation has been divided into three main stages, each of which can be further subdivided into several steps (Vincent, 1980). First, in the so-called preinfection stage (stage 1), rhizobia attach to the root hairs and root hair deformation occurs. Next, in the infection and nodule formation stage (stage 2), infection threads containing rhizobia penetrate into roots, a nodule structure is formed, and bacteria are then released in plant cells and develop into bacteroids. Finally, in the nodule function stage (stage 3 ), the root nodule becomes a functional, nitrogen-fixing organ.

As has been shown by genetic studies, plant genes are involved in each defined step of root nodule formation (for an overview, see Vincent, 1980). However, none of the

\footnotetext{
${ }^{1}$ Current address: Department of Molecular Cell Biology, State University, P.O. Box 80056, 3508 TB Utrecht, The Netherlands.

${ }^{2}$ To whom correspondence should be addressed.
}

genes concerned has been cloned and, as a consequence, the characteristics of these genes and the encoded proteins remain unknown. On the other hand, nodule-specific plant proteins, nodulins, have been described (van Kammen, 1984) and are studied extensively. They have been divided into early and late nodulins. Late nodulin genes are first expressed during stage 3 of nodule development, when infection of the roots by bacteria has taken place and a nodule structure has been formed. Hence, the expression of these genes is not related to the first two stages of nodule development. On the other hand, early nodulin genes are expressed during stages 1 and 2 of root nodule formation (Govers et al., 1985; Gloudemans et al., 1987). Late nodulin mRNAs have been cloned from several legumes, including pea (Govers et al., 1987). cDNA clones representing early nodulins have been obtained from soybean (Franssen et al., 1987, 1988), alfalfa (Dickstein et al., 1988), and pea (Scheres et al., 1990; van de Wiel et al., 1990). The pea early nodulin cDNA clone pPsENOD2 is homologous to the soybean pGmENOD2, and the product it codes for has been shown to be involved in the formation of the nodule parenchyma (inner cortex) surrounding the central nodule tissue (van de Wiel et al., 1990). The pea ENOD12 early nodulin is involved in the infection process 
(Scheres et al., 1990). Both ENOD2 and ENOD12 are proline-rich proteins composed of repeating pentapeptide units containing two (hydroxy-) prolines and are thought to be cell wall proteins.

The aim of this study was to obtain a set of pea early nodulin cDNA clones representing genes involved in the second stage of nodule development, when infection and nodule development take place. Both processes occur in pea nodules of 10-day-old pea plants when late nodulin mRNAs are not yet present (Govers et al., 1985). Therefore, we screened a nodule $C D N A$ library with cDNA probes of RNA from nodules of 10-day-old plants and uninfected roots, respectively. In this paper we describe the characterization of three early nodulin cDNA clones, pPsENOD5, pPsENOD3, and pPSENOD14, and compare the spatial distribution of the corresponding mRNAs in the developing pea nodule with that of the PPSENOD2 and pPsENOD12 mRNAs by in situ hybridization. The results show that we now have a series of CDNA clones corresponding to nodulin genes that are expressed in a sequential order and are related to different steps in the second stage of root nodule formation.

\section{RESULTS}

\section{Isolation and Characterization of Early Nodulin cDNA} Clones

We differentially screened a nodule cDNA library with cDNA probes prepared from mRNA of roots of 8-day-old uninoculated pea plants and nodules of 10-day-old plants. In this way we obtained three early nodulin cDNA clones, pPsENOD5, pPsENOD3, and pPSENOD14. The characteristics of these cDNA clones were determined and compared with those of the previously studied CDNA clones pPsENOD12 (van de Wiel et al., 1990) and pPsENOD12 (Scheres et al., 1990).

The time course of appearance of the various early nodulin mRNAs during nodule development was studied by RNA transfer blot analyses. Identical blots containing total RNA from roots of 8-day-old uninoculated plants, root segments of 8-day-old inoculated plants, and nodules of $10-, 13-$, and 17-day-old plants were hybridized to the inserts of the three newly isolated early nodulin clones and the inserts of pPSENOD2 and pPSENOD12, as shown in Figure 1. ENOD12 mRNA was already detectable in root segments of 8-day-old inoculated plants, then accumulated to maximum amounts from days 10 to 13 and, after that, decreased in concentration. ENOD5 mRNA was first detectable at day 10 , reached a maximum level around day 13 , and subsequently decreased in concentration. The ENOD2 mRNA was first detectable at day 10 on these RNA blots and increased in concentration during the next 7 days. The accumulation patterns of both ENOD3 and

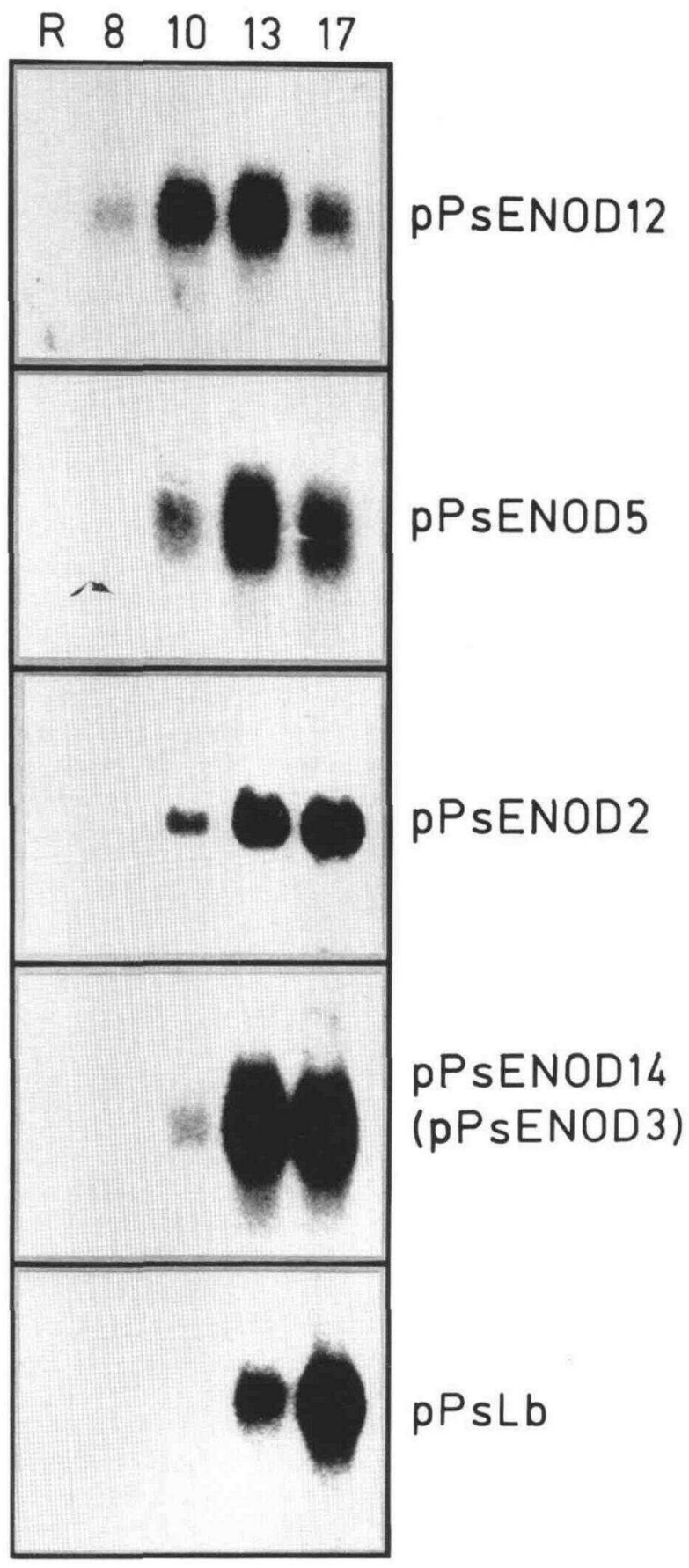

Figure 1. RNA Transfer Blot Analysis of RNA from Roots and Nodules.

RNA transfer blots contain $10 \mu \mathrm{g}$ of total RNA from uninoculated roots of 8 -day-old plants $(R)$, and nodules 8 days, 10 days, 13 days, and 17 days after sowing and inoculation, as indicated. Similar blots were probed with pPsENOD12, pPsENOD5, pPsENOD2, pPsENOD14, and pPsLb inserts, respectively. The measured sizes of the detected transcripts are $700 \mathrm{nt}, 700 \mathrm{nt}, 1400$ $\mathrm{nt}, 500 \mathrm{nt}$, and $650 \mathrm{nt}$, respectively. 
ENOD14 mRNAs during nodule development were similar. Both transcripts (only hybridization to ENOD14 is shown) were first detectable at day 10. The transcripts reached their maximum concentration around day 13 and maintained this concentration thereafter. Leghemoglobin (Lb) mRNA was included in the experiment as a typical example of a late nodulin transcript. Lb mRNA was first detectable at day 13 and the concentration of the transcript increased thereupon. None of the (early) nodulin mRNAs was detectable in uninoculated pea roots (Figure 1), neither in hypocotyl, epicotyl, plumule, stem, leaf, nor flower tissue (data not shown), with the exception of ENOD12 mRNA. As was reported previously (Scheres et al., 1990), ENOD12 transcripts are detectable at low levels in stem and flower tissue.

To examine whether the identified early nodulin genes are specifically expressed during the symbiotic interaction of Rhizobium and legumes but not during pathogenic interactions of microorganisms and pea roots, we studied whether early nodulin genes are expressed during infection of pea roots with the pathogenic fungus Fusarium oxysporum f.sp. pisi. Earlier we established that during this pathogenic interaction, the ENOD12 early nodulin gene, which is involved in the bacterial infection process, is not expressed (Scheres et al., 1990). Similar experiments showed that ENOD5, ENOD3, and ENOD14 transcripts are equally not detectable in pea roots upon inoculation with F. oxysporum (data not shown). Therefore, the accumulation of these early nodulin transcripts during nodule formation cannot be attributed to a general defense response.

Hybrid-released translation of mRNA, selected with the inserts of pPsENOD5, pPsENOD3, and pPsENOD14, was performed to determine the size of the corresponding primary translation products. The insert of pPsENOD5 selected an mRNA that upon translation produced a 14kD polypeptide, whereas the ENOD3 and ENOD14 mRNAs both encoded a 6-kD polypeptide, as shown in Figure 2. On a DNA gel blot containing pea genomic DNA digested with EcoRI, pPsENOD5 hybridized to a single 6.5-kb fragment, pPsENOD3 to a single 6.0 -kb fragment, and pPsENOD14 to fragments of $15 \mathrm{~kb}$ and $6.7 \mathrm{~kb}$, and also, with lower intensity, to fragments of $7.5 \mathrm{~kb}$ and 2.5 $\mathrm{kb}$. None of the cloned cDNAs hybridized to Rhizobium DNA (data not shown). In conclusion, pPsENOD5 and pPsENOD3 appear to represent single or low copy plant genes, whereas pPsENOD14 might represent a member of a small gene family.

\section{Sequence Analysis of pPsENOD5, pPsENOD3, and pPsENOD14}

Further information about the nature of the early nodulins encoded by the different cDNA clones was obtained by determining the nucleotide sequence of the inserts of
pPsENOD5, pPsENOD3, and pPsENOD14. The cDNA insert of pPsENOD5 is $553 \mathrm{bp}$ in length and has a polyA stretch at the $3^{\prime}$ end of the sequence, whereas the corresponding mRNA has a size of 700 nucleotides (nt), as determined on an RNA transfer blot. By direct RNA sequencing, the sequence of 20 nucleotides from the $5^{\prime}$ end of the mRNA missing in the cDNA clone was determined, indicated by lowercase letters in Figure 3 . The full sequence contained one large open reading frame that presumably starts with the first in-frame ATG codon at position -5 , as the sequences surrounding this ATG meet the requirements for the start codon consensus in plants (Lütcke et al., 1987). The encoded protein of 135 amino acids had a calculated molecular weight of $14 \mathrm{kD}$, which matched exactly the value of the apparent molecular weight of the polypeptide produced upon hybrid released translation. The protein sequence is characterized by hydrophobic domains at the amino, as well as at the carboxy, terminus (overlined). The $\mathrm{N}$-terminal hydrophobic domain

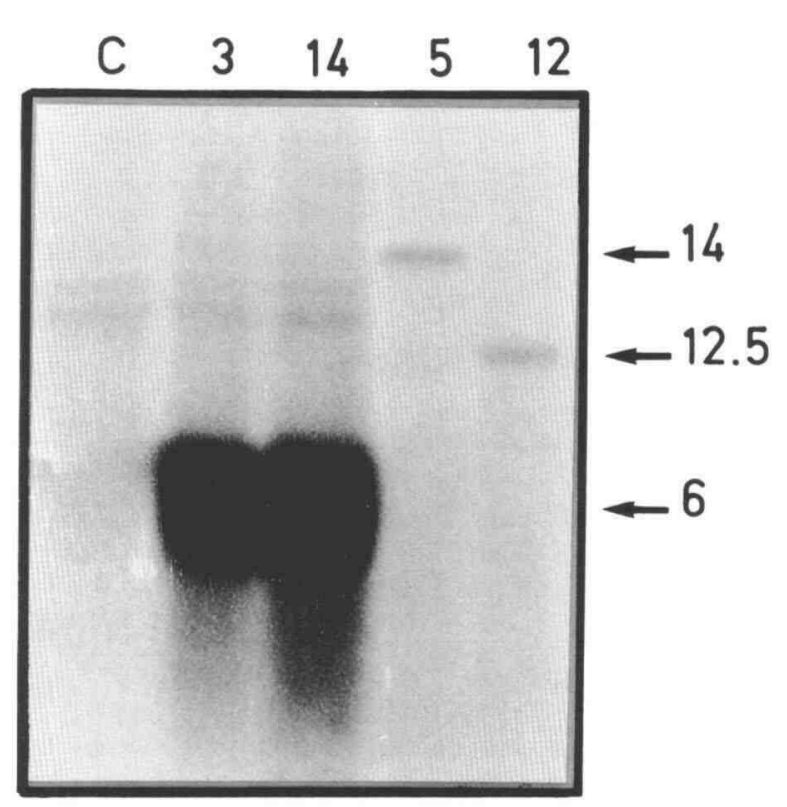

Figure 2. In Vitro Translation Products of Hybrid Selected Early Nodulin mRNAs.

Early nodulin mRNAs were selected from total nodule RNA and translated in vitro in the presence of ${ }^{35} \mathrm{~S}$-methionine as radioactive amino acid. Filters used for hybrid selection contained pBR322 (C), the inserts of pPsENOD3 (3), pPsENOD14 (14), and pPsENOD5 (5), and pPSENOD12 (12). In lanes C, 3, and 14, total RNA from nodules of 20-day-old plants was used; in lanes 5 and 12 , total RNA from nodules of 13-day-old plants was used. The size (in kilodaltons) of the in vitro translation products as determined by comparison with size markers is indicated at the right. A shorter exposure of lanes 3 and 14 did not reveal the presence of multiple bands. 


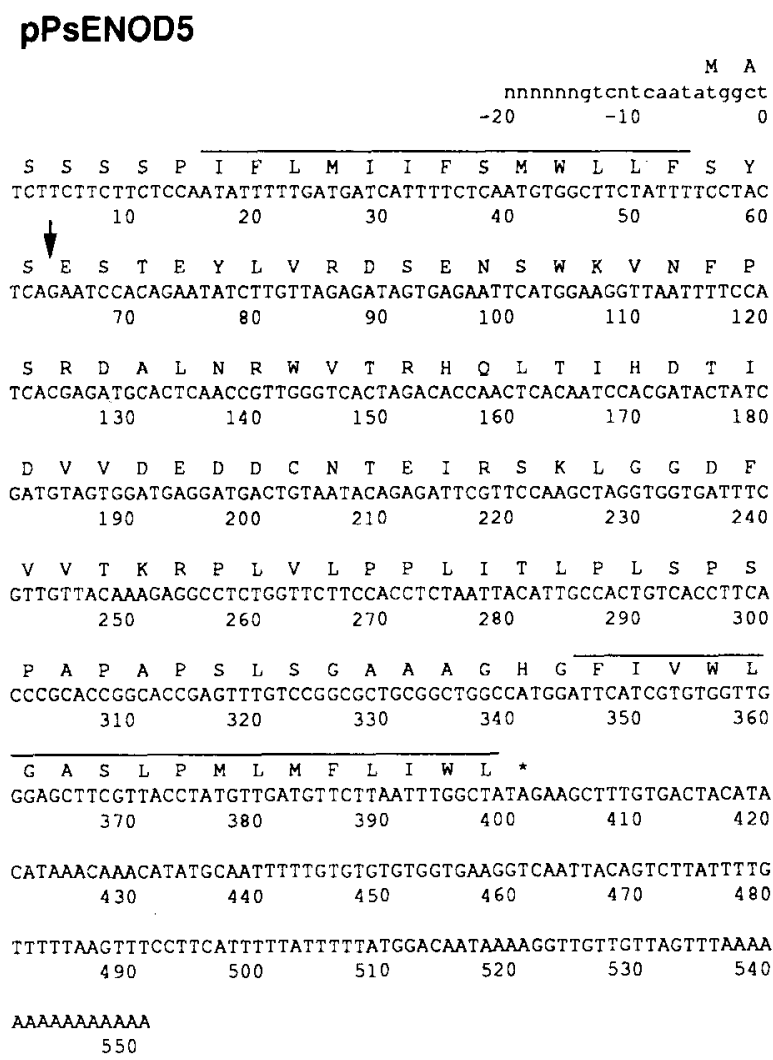

Figure 3. Nucleotide Sequences and the Deduced Amino Acid Sequences of the inserts of pPSENOD5, pPSENOD3, and pPsENOD14.

The amino acid sequences of the only long open reading frames present in the nucleotide sequences of the inserts of pPSENOD5, pPsENOD3, and pPsENOD14 are depicted over the nucleotide sequences. In pPSENOD5 and PPsENOD3 the sequence from the $5^{\prime}$ end of the mRNA to the first base present in the cDNA clone (numbered 1) is indicated in lowercase letters. Putative signal peptide cleavage sites are marked with arrows. In the pPsENOD5 sequence hydrophobic regions are overlined. Termination codons ending the reading frames are marked with an asterisk.

can be the core of a signal peptide of which the putative cleavage site (indicated by an arrow) can be predicted if the rules of Von Heijne (1983) are applied. Between amino acids 88 and 108 the polypeptide has a high proline content, and in that part of the sequence prolines are alternated by either serines or alanines. A computer search of the National Biomedical Research Foundation data base revealed no significant homology to other proteins. The high percentage of Pro, Ser, Ala, and Gly residues in the ENOD5 protein is reminiscent of the amino acid composition of arabinogalactan proteins (van Holst et al., 1981), of which, however, no sequences have been published so far. The small size of the ENOD5 protein is also consistent with the low protein content of arabinogalactan proteins (Fincher et al., 1983).

\section{pPsENOD3}

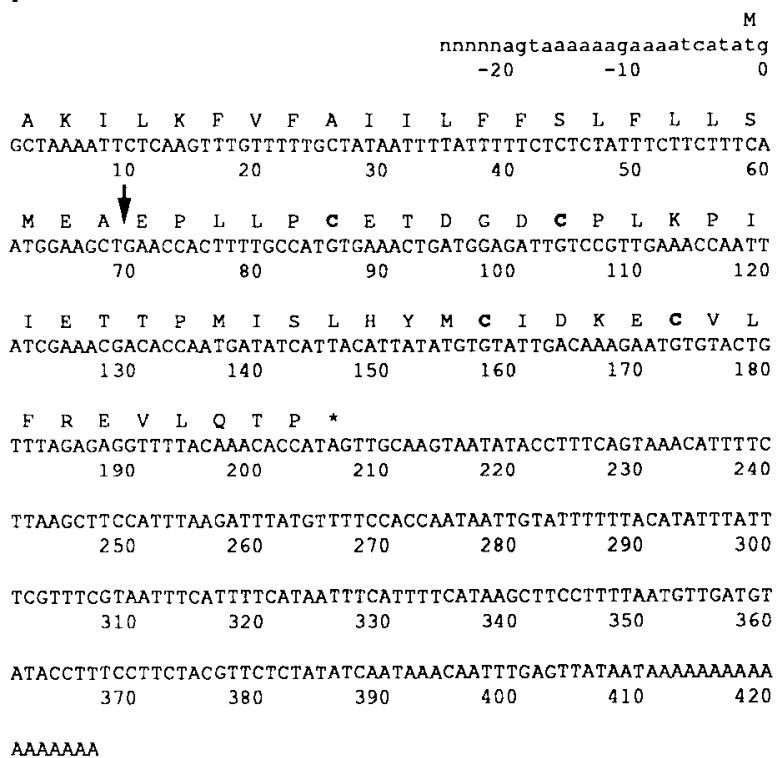

\section{pPsENOD14}

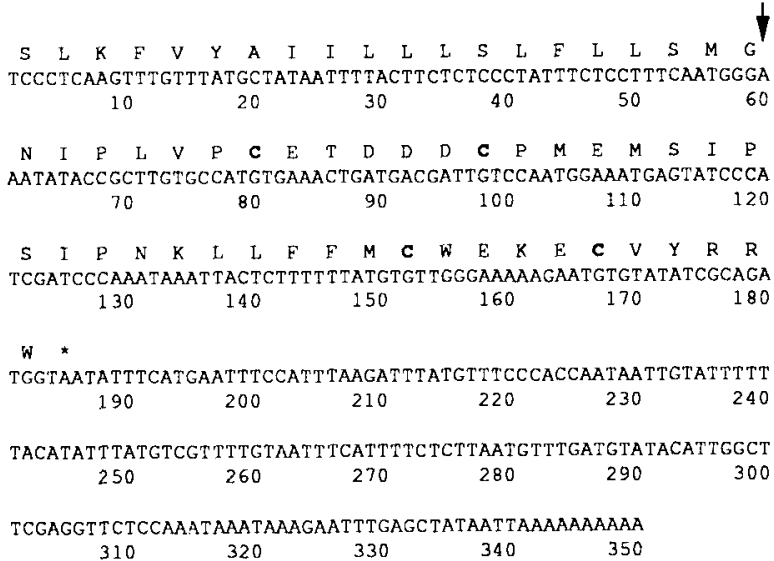

The cDNA insert of pPsENOD3 is $430 \mathrm{bp}$ in length and has a poly $(A)$ stretch at the $3^{\prime}$ end of its sequence. The corresponding mRNA appears as 550 nucleotides on an RNA transfer blot. The sequence of 25 nucleotides from the $5^{\prime}$ end of the mRNA, missing in the cDNA clone, was again determined by direct RNA sequencing (Figure 3 , lowercase letters). The final cDNA sequence reveals a single large open reading frame starting with the ATG codon at position -2 (Figure 3 ) that conforms to the rules for initiation codons in plants (Lütcke et al., 1987). The calculated molecular weight of the encoded protein is 8 $k D$, slightly larger than the size determined for the polypeptide produced upon hybrid released translation. The protein has a putative signal peptide at the $\mathrm{N}$ terminus, for which the predicted cleavage site in the amino acid se- 
quence (Von Heijne, 1983) is marked with an arrow. A remarkable feature of the protein sequence is the presence of 4 cysteines (bold typeface) arranged in two pairs in such a way that they might be capable of binding a metal ion (Berg, 1986).

pPSENOD14 has an insert of 350 bp with a poly $(A)$ stretch at the $3^{\prime}$ end of its sequence. Although the mRNA was estimated to measure $500 \mathrm{nt}$ on an RNA transfer blot, primer extension analysis showed that $29 \mathrm{nt}$ from the $5^{\prime}$ end of the mRNA are missing in the cloned CDNA (data not shown). The only long open reading frame in the cDNA sequence starts at the $5^{\prime}$ end and runs up to nucleotide 181 , encoding an amino acid sequence of 61 amino acids. The ENOD14 and the ENOD3 cDNA sequences are $65 \%$ homologous. The homology is found in the coding as well as in the noncoding regions, as can be seen in Figure 4A. The amino acid sequences of ENOD3 and ENOD14 are $55 \%$ homologous (Figure $4 \mathrm{~B}$ ), which is lower than the $65 \%$ homology between ENOD3 and ENOD14 on the DNA sequence level. This discrepancy is due to a large number of single base substitutions leading to amino acid substitutions. The $\mathrm{N}$ termini of ENOD3 and ENOD14 are $70 \%$ homologous. Therefore, we assume that, like ENOD3, ENOD14 will also have a signal peptide. The predicted signal peptide cleavage site (Von Heijne, 1983), assuming that the hydrophobic regions in the ENOD3 and ENOD14 $\mathrm{N}$ termini have a similar size, is indicated with an arrow in Figure 3. Just like the ENOD3 sequence, the amino acid sequence of the ENOD14 protein contains two cysteine pairs (bold typeface) and the distance between them is the same in both proteins. Although the amino acids surrounding the cysteines are well conserved, the region between the two cysteine pairs shows substantial variation among the ENOD3 and ENOD14 proteins (Figure 4B). Neither ENOD3 nor ENOD14 is homologous to late nodulins in soybean that contain cysteines with a similar spacing (Jacobs et al., 1987; Sandal et al., 1987). Both proteins do not have the characteristics of DNA-binding proteins with zinc fingers, containing similarly spaced cysteines (Berg, 1986). Furthermore, searching the National Biomedical Research Foundation data base did not reveal any other proteins with significant amino acid sequence homology to ENOD3 and ENOD14.

\section{Spatial Distribution of Early Nodulin Transcripts in Pea Root Nodules}

The distribution of the different early nodulin transcripts over the nodule tissue was studied in serial sections of nodules from 10-day-old and 16-day-old pea plants. Because pea nodules have a persistent meristem, the nodule tissues are of graded age from the apical meristem up to the root attachment point. A single longitudinal nodule section thus comprises various successive developmental stages of each particular cell type. The left panels of
Figures 5 and 6 show longitudinal sections of a nodule from 10-day-old and 16-day-old plants, respectively. The central part of the nodule can be divided into several zones (Newcomb, 1976). The meristem (M) is present at the apex. Adjacent to the meristem is the invasion zone (IZ), where infection thread growth and release of rhizobia occur. This zone is followed by the early symbiotic zone (ES) where the infected cells, containing bacteria, and the uninfected cells can first be distinguished and bacterial proliferation and cell enlargement occur. The zone with fully elongated cells containing bacteroids, which are able to fix nitrogen, is the late symbiotic zone (S). This tissue is still lacking in nodules from 10-day-old plants but is clearly visible in sections of nodules from 16-day-old plants (compare Figure 5 and Figure 6). Several other tissues surrounding the central part of the nodule are also derived from the apical meristem: the cortex (previously outer cortex, van de Wiel et al., 1990), the endodermis, the nodule parenchyma (previously inner cortex, van de Wiel et al., 1990), and the vascular tissue. Sections were analyzed by in situ hybridization using ${ }^{35} \mathrm{~S}$-labeled antisense and sense RNA probes transcribed from the inserts of pPsENOD12, pPsENOD5, pPsENOD3, pPsENOD14, and pPsLb101 (Govers et al., 1985), the latter representing the late nodulin leghemoglobin. Whereas none of the sense$$
\text { A }
$$

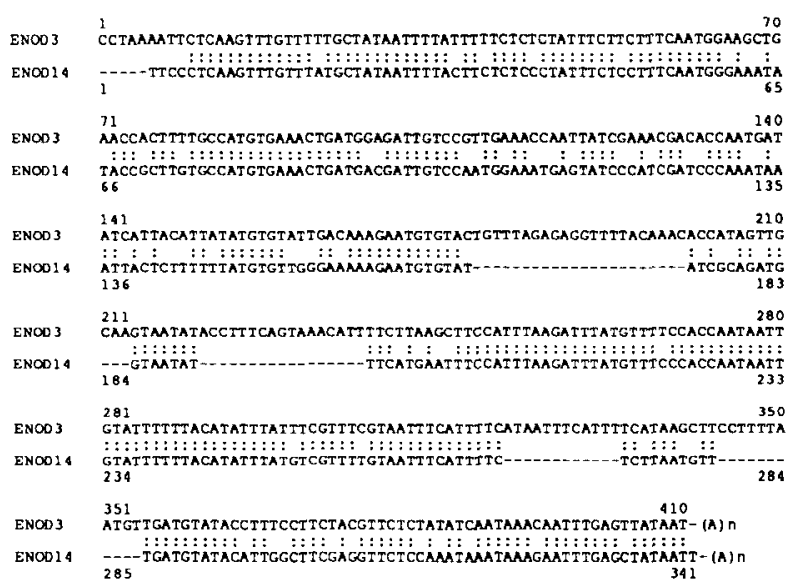$$
\text { B }
$$

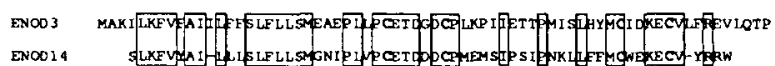

Figure 4. Alignment of ENOD3 and ENOD14 Nucleotide and Amino Acid Sequences.

(A) Alignment of the nucleotide sequences of the pPsENOD3 and pPsENOD14 cDNA inserts. Dots mark homologous bases.

(B) Alignment of the ENOD3 and ENOD14 amino acid sequences. Homologous amino acids are boxed. 
10 days
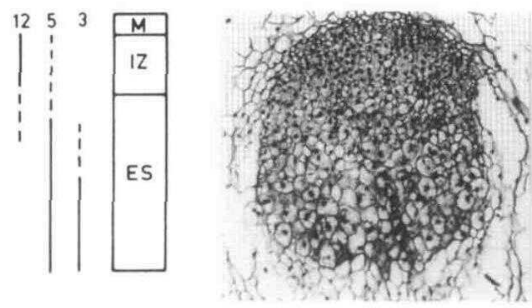

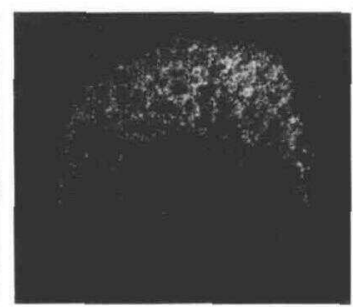

ENOD12

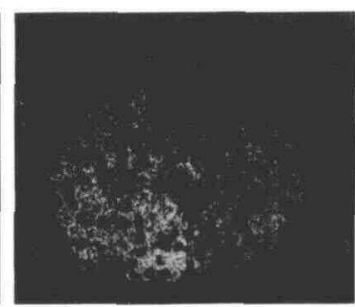

ENOD5

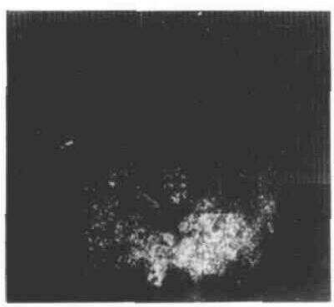

ENOD3

Figure 5. Localization of ENOD12, ENOD5, and ENOD3 Transcripts in Nodules from 10-Day-Old Pea Plants.

The left panel is a bright-field micrograph of a longitudinal section of a nodule from a 10-day-old pea plant. The position of different zones in the central part of the nodule from top to basis is depicted to the left: meristem (M), invasion zone (IZ), and early symbiotic zone (ES). The dark panels are aligned epipolarization micrograph montages from longitudinal serial sections of the same 10-day-old nodule shown in the left panel. Silver grains representing hybridization signal are visible as white spots. Sections were hybridized with ${ }^{35} \mathrm{~S}-\mathrm{labeled}$ antisense RNA probes transcribed from the inserts of pPSENOD12, pPSENOD5, and pPSENOD3, respectively. The zones where the different transcripts are located in the center of the nodule are aligned to the left of the figure: $12=E N O D 12,5=E N O D 5,3=E N O D 3$. Unbroken lines, high amount of transcript; dashed lines, low amount of transcript. Magnification $\times 33$.

RNA probes hybridized to the sections at detectable levels (data not shown), the antisense probes hybridized with RNA present in different regions of the central tissue of the nodule, with the exception of the ENOD2 probe. ENOD2 mRNA has been detected in the nodule parenchyma as described in a recent paper by van de Wiel et al. (1990). In situ hybridizations with the ENOD12 transcript were included in these studies to allow direct comparison of the zones in the central tissue in which the various early nodulin genes are expressed.

In nodules from 10-day-old plants, ENOD12 transcript was present in the invasion zone (Figure 5). The cells of the invasion zone directly adjacent to the meristem contained the largest proportion of the ENOD12 transcripts, whereas in the early symbiotic zone the amount of ENOD12 transcripts was falling off. This decrease of ENOD12 mRNA in the early symbiotic zone was also observed in sections from nodules of 16-day-old plants shown in Figure 6. ENOD12 mRNA was absent in the older part of the early symbiotic zone and in the symbiotic zone. The occurrence of ENOD12 transcript in the invasion zone containing growing infection threads, together with its presence in root hairs and root cortex cells through which infection threads pass, have led to the conclusion that this early nodulin is involved in the infection process (Scheres et al., 1990).

Low amounts of ENOD5 transcripts were detected in the youngest cells of the invasion zone directly adjacent to the apical meristem in nodules from 10-day-old plants. The largest amount of ENOD5 mRNA was present in the early symbiotic zone, in which bacterial proliferation and enlargement of the infected cells occur (Newcomb, 1976, and Figure 5). In nodules from 16-day-old plants it can be seen that after reaching its maximum concentration in the early symbiotic zone, the amount of ENOD5 transcript decreased rapidly in the late symbiotic zone, where it remained at a constant low level (Figure 6).

The location of ENOD3 and ENOD14 transcripts was found to be the same and, therefore, only pictures of the localization of ENOD3 mRNA are shown. In nodules from 10-day-old plants ENOD3 mRNA was present in the older part of the early symbiotic zone, where cells had already substantially enlarged and in which ENOD12 transcript was no longer detected (Figure 5). The ENOD3 and ENOD14 transcripts were thus first detectable at a later stage of development than the ENOD12 and ENOD5 mRNAs. In nodules from 16-day-old plants ENOD3 transcript appeared to reach its maximum proportion in the symbiotic zone, where the amount of ENOD5 mRNA was decreasing (Figure 6). In nodules from 16-day-old plants the oldest cells of the symbiotic zone showed a decrease in ENOD3 mRNA. In such cells, where the ENOD3 mRNA concentration diminished, the bacterial nifH mRNA encoding nitrogenase is first detectable with in situ hybridization (T. Bisseling, unpublished results). Maximum amounts of ENOD3 transcript and of ENOD14 mRNA are present, therefore, in the symbiotic zone just before the stage at which the bacteria start to fix nitrogen.

In nodules from 16-day-old plants Lb transcripts were first detectable in cells of the late symbiotic zone, where the level of ENOD3 mRNA is maximal (Figure 6). Therefore, the Lb mRNA concentration reached its maximum amount at a later stage than ENOD3 $\mathrm{mRNA}$ and remained at a high level in older parts of the symbiotic zone.

The central tissue of the nodule contains both the infected and the uninfected cell type. The data obtained with ${ }^{35}$ S-labeled probes clearly showed that all different early nodulin transcripts were present in the infected cell type. 

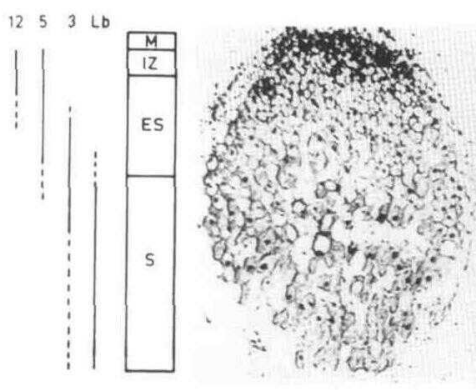

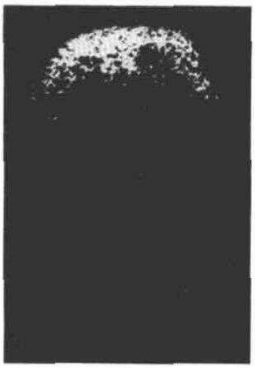

ENOD12

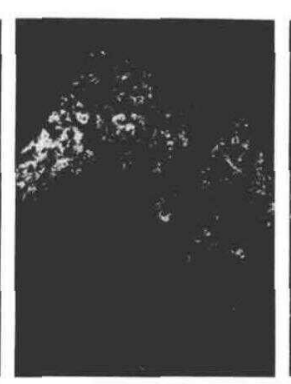

ENOD5

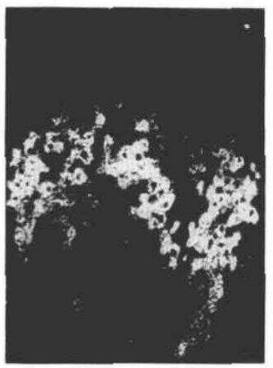

ENOD3

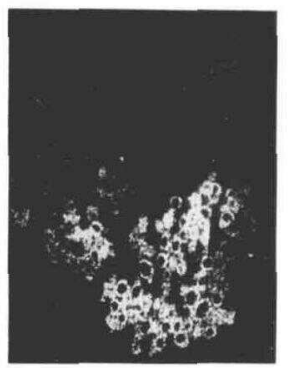

Lb

Figure 6. Localization of ENOD12, ENOD5, ENOD3, and Leghemoglobin Transcripts in Root Nodules from 16-Day-Old Pea Plants.

The left panel is a bright-field micrograph of a longitudinal section of a nodule from a 16-day-old pea plant. The position of zones in the central part of the nodule is depicted to the left: meristem (M), invasion zone (IZ), early symbiotic zone (ES), and late symbiotic zone (S). The dark panels are aligned epipolarization micrograph montages from longitudinal serial sections of the 16-day-old nodule shown in the left panel. Silver grains representing hybridization signal are visible as white spots. Sections were hybridized with ${ }^{35} \mathrm{~S}-\mathrm{labeled}$ antisense RNA probes translated from the inserts of pPSENOD12, pPSENOD5, pPsENOD3, and pPsLb1, respectively. The zones where the different transcripts are located in the center of the nodule are aligned to the left of the figure: $12=\mathrm{ENOD} 12,5=\mathrm{ENOD} 5,3=\mathrm{ENOD} 3, \mathrm{Lb}=$ leghemoglobin. Magnification $\times 36$.

On the other hand, it was not possible to exclude that transcripts were also present in the highly vacuolated, uninfected cells using ${ }^{35} \mathrm{~S}$-labeled probes. Therefore, we also hybridized sections from nodules of 16-day-old plants with ${ }^{3} \mathrm{H}$-labeled probes, which allow more accurate localization. Figures $7 \mathrm{~A}$ and $7 \mathrm{~B}$ show that ENOD12 transcripts appeared to be present in all cells of the invasion zone, regardless of whether they developed into infected or uninfected cells. The ENOD5, ENOD3, and Lb transcripts all appeared to be detectable in the infected cells, but not in the thin layer of cytoplasm lining the cell wall of the highly vacuolated noninfected cells, which can be observed in Figures 7C, 7D, and Figure 8.

\section{Localization of ENOD5 and ENOD12 Transcripts at Early Stages of Root Nodule Development}

ENOD5 and ENOD12 transcripts were both detected in the youngest cells of the invasion zone, but whereas the ENOD12 transcript was present in these cells at maximum concentration, the ENOD5 mRNA was present at low concentration, and this transcript reached its maximum concentration later in the early symbiotic zone. These data suggest that the ENOD5 gene is induced at a later stage of root nodule development than the ENOD12 gene. To test this assumption, we hybridized ${ }^{35}$ S-labeled ENOD5 and ENOD12 antisense RNA to sections of pea roots containing earlier stages of nodule development. In the root inner cortex of 6-day-old plants, inoculated 3 days after sowing, the penetrating infection thread was visible in the outer root cortex, as indicated by the arrows in Figures $9 \mathrm{~A}$ and $9 \mathrm{C}$, whereas the nodule primordium was developing in the inner cortex. ENOD5 transcript was only detectable in root cortex cells containing the infection thread tip and in the cells through which the infection thread had just passed, and not in the nodule primordium (Figure 9B). On the other hand, ENOD12 mRNA was present in the cells carrying the invading infection thread and also in the nodule primordium (Figure 9D). In 8-dayold plants the infection thread had reached the nodule primordium (Figures $9 \mathrm{E}$ and $9 \mathrm{G}$ ). At that stage ENOD5 transcript was detected in cells in the center of the primordium (Figure 9F). Analyses at higher magnifications showed that these cells contain branches of the infection thread (data not shown). The ENOD12 mRNA was present in all cells of the nodule primordium (Figure $9 \mathrm{H}$ ). Hence, ENOD5 and ENOD12 genes appear to be expressed at the same stage of the Rhizobium-pea interaction. There is, however, a major difference in accumulation of the transcripts during early stages of root nodule development: the ENOD5 transcript is restricted to the cells containing the actively growing infection thread, whereas ENOD12 mRNA is present well in advance of the growing thread.

\section{DISCUSSION}

\section{Early Nodulin Transcripts Mark Successive Stages of Root Nodule Development}

Three early nodulin transcripts that are present in successive zones of the central tissue of the indeterminate pea nodule were characterized. Together with the previously 


\section{ENOD 12}
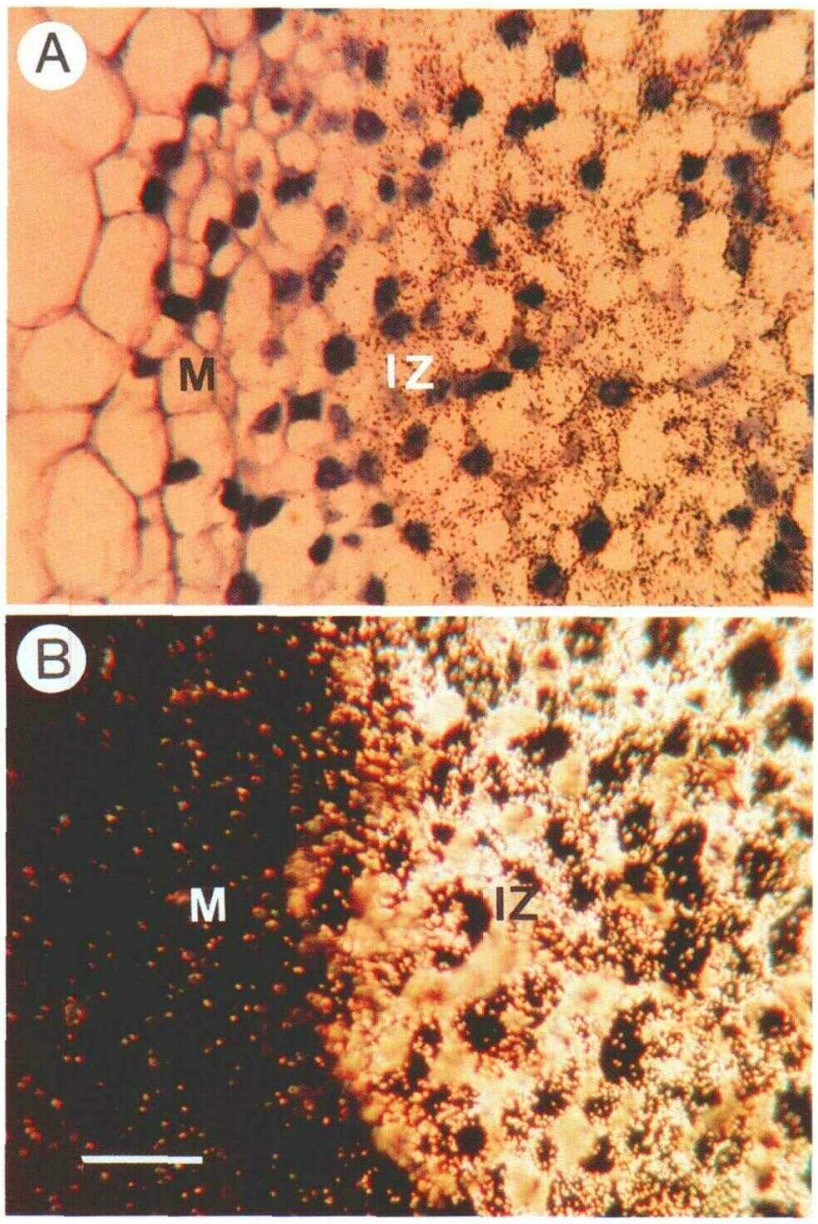

ENOD 5
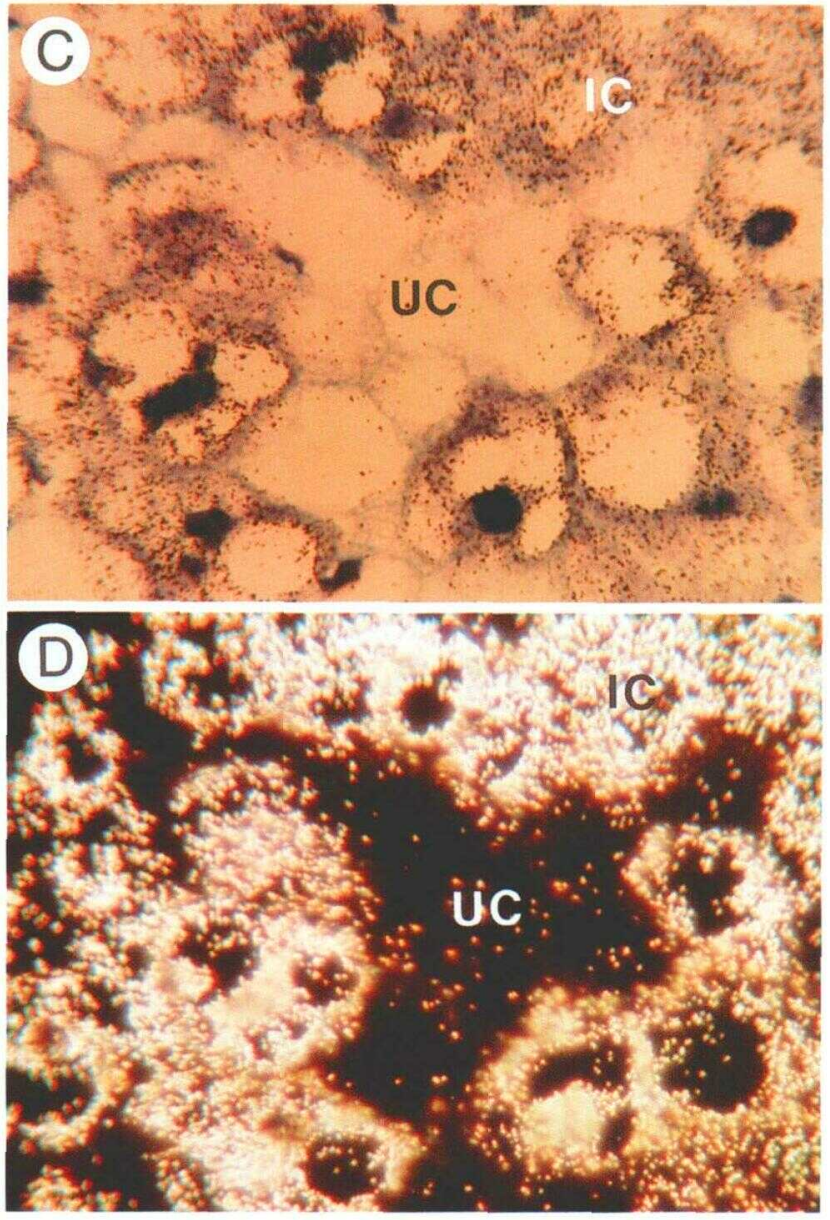

Figure 7. Localization of ENOD12 and ENOD5 Transcripts Using ${ }^{3} \mathrm{H}$-Labeled Probes.

The lower panels show epipolarization micrographs corresponding with the bright-field micrographs in the upper panels.

(A) and (B) Longitudinal section through the meristem (M) and invasion zone (IZ) of a nodule from a 16-day-old pea plant.

(C) and (D) Longitudinal section through a nodule from a 16-day-old pea plant showing a part of the symbiotic zone. Infected cells (IC) contain bacteria, and uninfected cells (UC) possess large vacuoles and cytoplasm with amyloplasts containing large starch grains that line the cell walls.

Sections were hybridized with ${ }^{3} \mathrm{H}$-labeled antisense RNA probes translated from the inserts of pPsENOD12 [(B)] and pPSENOD5 [(D)] respectively. Bar $=50 \mu \mathrm{m}$.

described early nodulin transcript ENOD12 and the leghemoglobin mRNA, they form a set of markers for successive developmental stages of the central tissue. Whereas ENOD12 mRNA was present in both infected and uninfected cells of the invasion zone, the ENOD5, ENOD3, ENOD14, and Lb transcripts were restricted to the infected cell type. Therefore, all five transcripts mark different developmental stages of the infected cells, which are part of the actual symbiotic tissue. The location of the different
mRNAs in the symbiotic tissue can be compared with the cytological zones according to Newcomb (1976), as indicated in Figures 5 and 6 . ENOD12 transcript was mainly present in the invasion zone, ENOD5 transcript in the invasion zone and the early symbiotic zone, and Lb mRNA in the late symbiotic zone. The location of these transcripts, therefore, roughly coincides with one or more zones described by cytological criteria. On the other hand, the location of ENOD3 and ENOD14 mRNA does not mark a 
ENOD 3
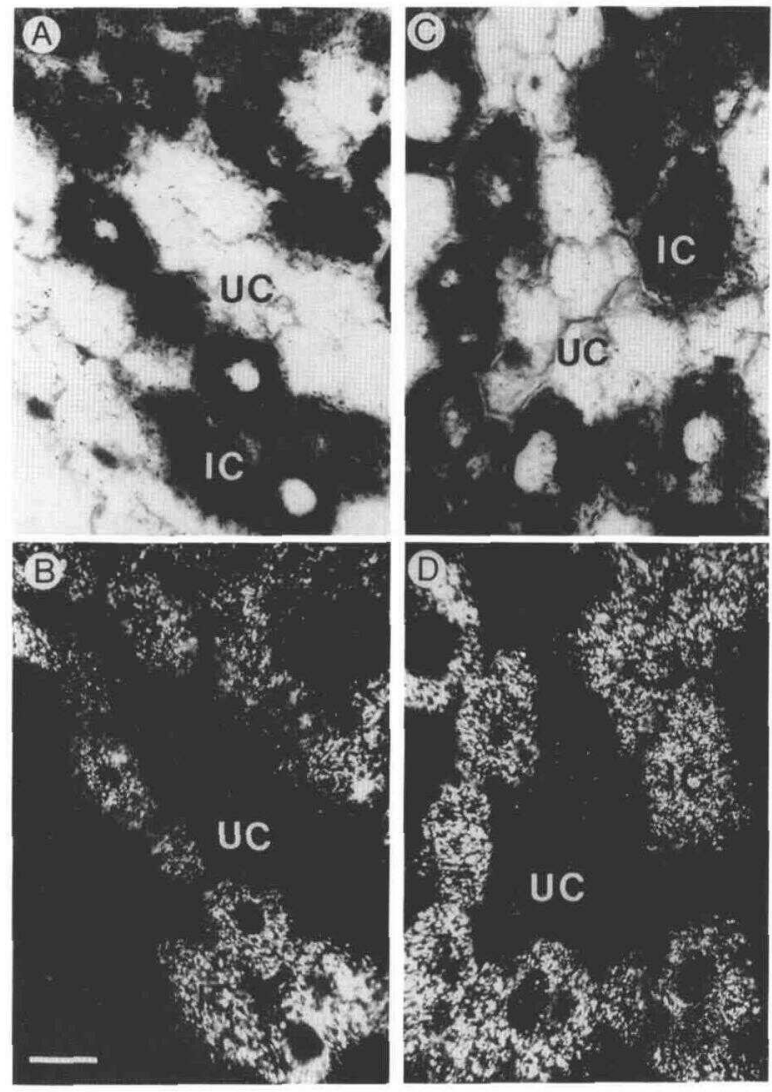

Figure 8. Localization of ENOD3 and Leghemoglobin Transcripts Using ${ }^{3} \mathrm{H}$-Labeled Probes.

The lower panels show epipolarization micrographs corresponding with the bright-field micrographs in the upper panels.

(A) and (C) Longitudinal sections through a nodule from a 16day-old pea plant showing a part of the symbiotic zone.

(B) ENOD3 mRNA localization in (A).

(D) Lb mRNA localization in (C).

Sections were hybridized with ${ }^{3} \mathrm{H}$-labeled antisense RNA probes translated from the inserts of pPsENOD3 [(B)] and pPsLb101 [(D)], respectively. IC, infected cell; UC, uninfected cell. Bar = $50 \mu \mathrm{m}$.

cytologically distinct zone. The possibility to describe root nodule development not only by cytological criteria but also in molecular terms facilitates analysis of wild-type and mutant root nodule development.

It has been recognized that nodulin genes are expressed at different time stages of nodule development (Govers et al., 1985; Gloudemans et al., 1987). This has led to the division between early and late nodulins. The accumulation of early nodulin transcripts in different zones of the pea nodule as shown in this paper implies that Rhizobium causes induction of nodulin gene expression at various timepoints. The division of nodulin genes into two classes according to their timing of expression should not be regarded as reflecting the actual existence of two main timepoints at which Rhizobium induces plant gene expression. Rather, it forms an arbitrary division within a set of genes induced by the bacterium in a sequential manner.

The accumulation patterns in time of different transcripts within the early nodulin class were visualized on RNA transfer blots, as can be seen in Figure 1, but were most clearly reflected by the in situ hybridization data. The apparent difference in time between the onset of ENOD12 and ENOD5 gene expression as deduced from RNA transfer blot analyses appeared not to be true. The in situ hybridization data showed that a few cells express the ENOD5 gene at an early stage of bacterial infection, but the amount of transcript is not sufficient to be seen on blots containing RNA extracts. Furthermore, it was more obvious from localization studies than from RNA transfer blots that the ENOD5 gene is expressed at an earlier stage of development than the ENOD3/14 genes. Finally, the transient accumulation patterns of ENOD12 and ENOD5 transcripts on an RNA transfer blot appear to reflect a decrease of the size of the zone in which the ENOD12 and ENOD5 mRNAs are present, relative to the total size of the nodule, rather than reflecting a decrease of the amount of transcript in a particular tissue zone.

\section{Possible Functions of Early Nodulins Located in the Central Nodule Tissue}

In nodules the ENOD12 gene is expressed in the invasion zone, the zone in which active infection thread growth occurs (Newcomb, 1976). In addition, ENOD12 gene expression is induced in root hairs, in root cortical cells through which the infection thread will migrate, and in the nodule primordium. It is likely that the proline-rich ENOD12 early nodulin is a cell wall component involved in preparing cells for the infection process, whereas the protein can also have a function in the formation of the nodule primordium (Scheres et al., 1990).

The ENOD5 gene was found to be expressed at early stages in cortex cells containing the infection thread tip, so expression of this gene is induced during the same stage of development as the ENOD12 gene. ENOD5 gene expression was detected in the invasion zone and not in the meristem, which is consistent with a role for ENOD5 in the infection process. However, the highest levels of the ENOD5 transcript were present in infected cells of the early symbiotic zone. Therefore, in the nodule the highest level of the ENOD5 transcript does not coincide with the zone where infection thread growth occurs. This might indicate that the protein is functional both during infection thread growth and bacterial proliferation. Cells containing 

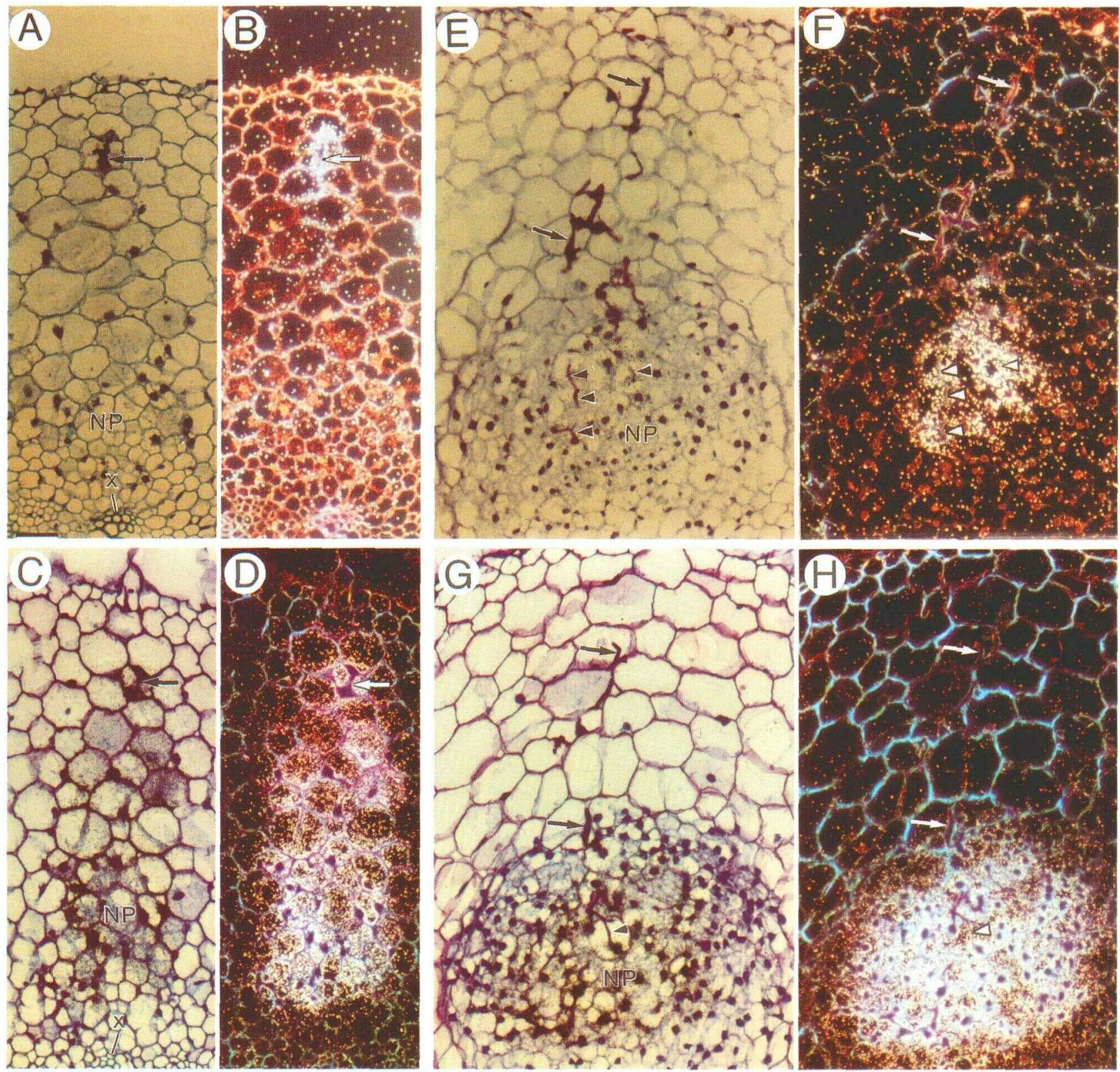

Figure 9. Localization of ENOD5 and ENOD12 Transcripts in Pea Root Segments

The (B), (D), (F), and (H) panels are dark-field micrographs corresponding with bright-field micrographs in the (A), (C), (E), and (G) panels, respectively. In the dark-field micrographs silver grains are visible as white spots.

(A) Root transection of 6-day-old pea plant 3 days after inoculation.

(B) ENOD5 mRNA localization in this transection.

(C) Root transection of 6-day-old plant at similar developmental stage as (A)

(D) ENOD12 mRNA localization in this transection.

(E) Transection through a pea root of 8-day-old plants 5 days after inoculation

(F) ENOD5 mRNA localization in this transection.

(G) Transection through a pea root of 8-day-old plants at similar developmental stage as (E).

(H) ENOD12 mRNA localization in this transection.

Sections were hybridized with ${ }^{35}$ S-labeled antisense ENOD5 and ENOD12 RNA. Bar $=50 \mu \mathrm{m}$. X, xylem pole of central cylinder. NP nodule primordium. Infection thread is indicated with arrows. Branches from the infection thread in the nodule primordium are indicated with arrowheads. 
the infection thread tip and cells containing released bacteria share as a common property the presence of rhizobia within the cell, only shielded from direct contact with the cytoplasm by the membrane surrounding the open infection thread tip or the peribacteroid membrane, respectively. The hydrophobic domains in the ENOD5 protein could point to a location of the protein within such membranes. On the other hand, the resemblance in amino acid composition of a central region of the ENOD5 protein to that of arabinogalactan proteins (AGPS) might indicate that ENOD5 is an extracellular protein present in both the infection thread matrix and the peribacteroid space. The functions of AGPs are as yet unknown (Fincher et al., 1983) but they are widely distributed, and organ-specific forms occur (Knox et al., 1989). In soybean nodules specific AGPs were detected, demonstrating that some nodulins can be AGPs (Cassab, 1986). We intend to establish whether ENOD5 is a nodule-specific AGP or a membraneassociated protein by immunological analyses with the aid of antisera raised against ENOD5 peptides.

The inserts of pPSENOD3 and pPsENOD14 are $65 \%$ homologous. However, on DNA gel blots these inserts do not cross-hybridize under standard conditions (data not shown). Therefore, we expect that also on nodule sections the ENOD3 and ENOD14 probes hybridize predominantly with their homologous RNAs. Because the ENOD3 and ENOD14 probes hybridized in the same zone of the nodule, it is very likely that these two early nodulin genes are expressed in infected cells during the same stage of development, when the bacteria have proliferated to a certain extent. Remarkably, although the expression behavior of the ENOD3 and ENOD14 genes is identical and the proteins have similar features, close comparison of the amino acid sequences reveals many amino acid substitutions, indicating that the functions of the proteins might be similar but not identical. The ENOD3 and ENOD14 proteins consist of a signal peptide and a small polypeptide containing 4 cysteines that may bind a metal ion. Therefore, we assume that these early nodulins have a metal ion transport function. Because the bacteroids require high amounts of molybdenum and iron for the synthesis of nitrogenase (Ljones, 1974), it is tempting to speculate that ENOD3 and ENOD14 have a role in the transport of these metals over the peribacteroid membrane to the bacteroid. Cysteine clusters and a putative signal peptide like in ENOD3 and ENOD14 are also present in a set of soybean nodulins, although there is no further sequence homology among these proteins (Jacobs et al., 1987; Sandal et al., 1987). One of these soybean proteins, $\mathrm{N}-23$, is located in the peribacteroid membrane (Jacobs et al., 1987) and, hence, like ENOD3 and ENOD14, present in infected cells. Nevertheless, it seems too early to speculate that these soybean and pea nodulins have similar functions based on the correlations mentioned above. The small size of the ENOD12, ENOD5, ENOD3, and ENOD14 proteins suggests that, in general, early nodulins are relatively small.
Nevertheless, we think that it is a coincidence that the clones described in this paper encode relatively small proteins because other early nodulins, like ENOD2 (Franssen et al., 1987) and $\mathrm{N}-40^{\prime}$ (Govers et al., 1985), have a larger size.

\section{Regulation of Early Nodulin Gene Expression by Rhizobium}

An intriguing question concerning the establishment of symbiosis is whether Rhizobium needs to elicit only a few or a multiplicity of signals to effect root nodule formation and the accompanying expression of nodulin genes. The availability of the set of CDNA clones described in this paper, representing genes expressed at different stages during nodule formation, adds to the possibility of exploring this problem.

In a previous paper we demonstrated that the ENOD12 gene is expressed in nodule primordia and root cortex cells that do not yet contain the infection thread, so a diffusible compound from Rhizobium, involved in inducing this early nodulin gene, seems to act over a rather large distance (Scheres et al., 1990). This is consistent with the finding that the ENOD12 gene is expressed not only in nodule cells containing bacteria but also in all cells of the invasion zone. The bacterial nodulation (nod) genes have been shown to be essential for ENOD12 gene expression, and soluble bacterial compounds are able to elicit ENOD12 gene expression in root hairs (Scheres et al., 1990).

Our studies of the distribution of ENOD5 mRNA during nodule development indicate that bacterial compounds inducing ENOD5 gene expression appear to be active only in cells containing bacteria surrounded by either the infection thread tip membrane or the peribacteroid membrane. Apparently, an intercellular barrier exists for the signal that induces ENOD5 gene expression. Hence, there is a clear difference in the way Rhizobium induces ENOD5 and ENOD12 gene expression. While a factor acting over a long range is inducing ENOD12 gene expression, most likely another factor acting over a short distance is inducing expression of the ENOD5 gene. The nature of the ENOD5inducing signal and the bacterial genes involved in producing it are still unknown. However, the low level of ENOD5 mRNA in the infected cells of the late symbiotic zone shows that the presence of rhizobia in a cell is not sufficient for the accumulation of the ENOD5 mRNA.

The observation that the amount of ENOD5 transcripts in the infected cells is already declining while the amount of ENOD3/14 transcript is maximal indicates that different bacterial factors may be responsible for the induction of ENOD5 and ENOD3/14 gene expression. In a similar way different bacterial factors may induce ENOD3/14 and $L b$ gene expression, respectively, because the amount of ENOD3/14 transcript decreases in the zone where the amount of leghemoglobin transcript becomes maximal. 
Alternatively, one bacterial signal, inducing a cascade of developmental events, may lead to differential expression of the ENOD5, ENOD3/14, and leghemoglobin nodulin genes. The argument for considering induction of ENOD12 and ENOD5 gene expression to be caused by different bacterial factors, namely the fact that one gene is induced at a distance from infected cells and the other gene is not, does not apply to the ENOD5, ENOD3/14, and Lb genes because these are all expressed in infected cells. Genetically defined bacterial mutants that do not produce the compounds necessary to invoke ENOD5, ENOD3/14, or Lb gene expression may provide clues to resolve whether one or more bacterial signals are involved in the induction of expression of these genes. Moreover, these mutants may be useful to elucidate the structure of different signal molecules. In this regard, the bacterial release (bar) (De Maagd et al., 1989) and bacteroid development (bad) mutants are promising because these mutants affect nodule development at the time that ENOD5 and ENOD3/14 genes are expressed.

\section{METHODS}

\section{Plant Materials}

Pea (Pisum sativum cv rondo or sparkle) plants were cultured and inoculated with Rhizobium leguminosarum bv viciae 248 , as described by Bisseling et al. (1978). Inoculation was performed directly upon sowing, unless stated otherwise. Nodules were excised from root tissue, except in the case of pea plants, 8 days after inoculation, and $2.5-\mathrm{cm}$ sections of the main root, where nodules would appear, were harvested. Uninfected pea plants were cultured in the same way, and pieces of the main root were collected 8 days after sowing. Fusarium oxysporum mycelium was inoculated in Czapek-dox medium and grown for 2 days at $30^{\circ} \mathrm{C}$. Pea plants were inoculated with this suspension 3 days after sowing and cultured as above. Root tissue was harvested after various incubation times. All plant tissues were frozen in liquid nitrogen immediately after harvesting and stored at $-70^{\circ} \mathrm{C}$.

\section{cDNA Cloning}

A $\lambda g t 11$ cDNA library, prepared from $P$. sativum cv sparkle lateral root nodule RNA, 21 days after infection, was kindly provided by Dr. G. Coruzzi (Tigney et al., 1987). Nitrocellulose replicas, containing phage DNA of approximately 3000 plaques, were made using standard procedures (Maniatis et al., 1982). ${ }^{32} \mathrm{P}$-labeled cDNA probes for differential screening were prepared from poly $(A)+$ RNA of nodules 10 days after inoculation and of 8-dayold uninfected roots. Replica filters were hybridized to either root or nodule cDNA as described by Franssen et al. (1987). Plaques, giving a nodule-specific signal, were purified using another differential screening. Phage DNA was isolated and cDNA inserts were subcloned into pUC vectors using standard procedures (Maniatis et al., 1982).

\section{RNA Transfer Blot Analysis}

Total RNA from nodules and other tissues was isolated by phenol extraction and $\mathrm{LiCl}$ precipitation according to De Vries et al. (1982). RNA concentrations were measured spectrophotometrically, and equal amounts of total RNA were used for gel blot analysis, as stated in the figure legends. RNA transfer blotting was performed as described by Franssen et al. (1987) using GeneScreen membranes and nick-translated CDNA inserts or antisense RNA probes.

\section{Genomic DNA Isolation and Blotting}

Genomic DNA from pea leaves was isolated using the cetyltrimethylammonium bromide method described by Rogers and Bendich (1988). Restriction enzyme digestions were performed under standard conditions. Digested DNA was transferred to GeneScreen-Plus membranes using ammonium acetate transfer (Rigaud et al., 1987). The blot was hybridized to nick-translated cDNA insert probes in $1 \mathrm{M} \mathrm{NaCl}, 1 \%$ SDS, $10 \%$ dextran sulfate, and $100 \mu \mathrm{g} / \mathrm{mL}$ denatured salmon sperm DNA at $65^{\circ} \mathrm{C}$ during 24 $\mathrm{hr}$. Subsequently, blots were washed, $2 \times 10 \mathrm{~min}$ in $2 \times$ SSC and $2 \times 20 \mathrm{~min}$ in $2 \times \mathrm{SSC} / 1 \% \mathrm{SDS}$ at $65^{\circ} \mathrm{C}$.

\section{Hybrid-Released Translation}

Selection of mRNA was done with inserts from the various CDNA clones, bound on diazophenylthio (DPT) paper (Bio-Rad), as described by Maniatis et al. (1982). Fifty micrograms of denatured DNA was spotted on DPT discs of $0.5 \mathrm{~cm}^{2}$. Hybridization to $1 \mathrm{mg}$ of total nodule RNA from 12-day-old plants was done in $300 \mu \mathrm{L}$ containing $50 \%(\mathrm{~V} / \mathrm{V})$ formamide, $0.1 \% \mathrm{SDS}, 0.6 \mathrm{M} \mathrm{NaCl}, 4 \mathrm{mM}$ EDTA, $80 \mathrm{mM}$ Tris- $\mathrm{HCl}, \mathrm{pH} 7.8$. Hybridization was initiated at $50^{\circ} \mathrm{C}$ and temperature was decreased to $37^{\circ} \mathrm{C}$ over a 6 -hr period. Hybrid-selected mRNA was translated in a wheat germ extract (Bethesda Research Laboratories) using ${ }^{35} \mathrm{~S}$-methionine (Du PontNew England Nuclear) as radioactive amino acid. Proteins were separated on SDS-containing $25 \%$ acrylamide gels. Gels were fluorographed to Kodak XAR-5 films.

\section{DNA Sequencing}

CDNA inserts were sequenced using the double-stranded dideoxy chain termination procedure (Korneluk et al., 1985). Both strands were sequenced entirely. In all cases two independently obtained clones were sequenced to rule out the possibility of recombined CDNAs. Sequence data were stored and analyzed using programs written by $R$. Staden on VAX/VMS and microVAX/VMS computers.

\section{In Situ Hybridization}

All cDNA inserts were cloned in pT7-6 (a kind gift of Dr. S. Tabor), and antisense RNA probes were transcribed using T7 RNA polymerase (New England Biolabs) and ${ }^{35} \mathrm{~S}-U T P$ (Du Pont-New England Nuclear, 1000 to $1500 \mathrm{Ci} / \mathrm{mmol})$ or ${ }^{3} \mathrm{H}-U T P(40 \mathrm{Ci} / \mathrm{mmol})$ as the 
radioactive nucleotide. The probes were partially degraded to an average length of 150 nucleotides by heating at $60^{\circ} \mathrm{C}$ for $90 \mathrm{~min}$ in $0.2 \mathrm{M} \mathrm{Na}_{2} \mathrm{CO}_{3} / 0.2 \mathrm{M} \mathrm{NaHCO}_{3}$. In situ hybridization studies were carried out by a method derived from the procedure described by Cox and Goldberg (1988) (van de Wiel et al., 1990). In brief, nodules, stems, and root sections were fixed with $3 \%$ paraformaldehyde and $0.25 \%$ glutaraldehyde in $0.1 \mathrm{M}$ sodium phosphate buffer, $\mathrm{pH} 7.4$. Dehydration was performed in graded ethanol, and xylene series and tissues were embedded in paraplast (Brunswick). Sections $7 \mu \mathrm{m}$ thick were attached to poly-Llysine-coated slides. Sections were deparaffinized with xylene and rehydrated through a graded ethanol series. They were pretreated with $1 \mu \mathrm{g} / \mathrm{mL}$ proteinase $\mathrm{K}$ in $100 \mathrm{mM}$ Tris/ $\mathrm{HCl}, \mathrm{pH} 7.5,50 \mathrm{mM}$ EDTA at $37^{\circ} \mathrm{C}$ for $30 \mathrm{~min}$ and $0.25 \%$ acetic anhydride in $0.1 \mathrm{M}$ triethanolamine, $\mathrm{pH} 8.0$, at room temperature for $10 \mathrm{~min}$. Subsequently, they were dehydrated in a graded ethanol series and air dried. Sections were hybridized with RNA probes $\left(10^{6} \mathrm{cpm} / \mathrm{mL}\right)$ in $50 \%$ formamide, $0.3 \mathrm{M} \mathrm{NaCl}, 10 \mathrm{mM}$ Tris- $\mathrm{HCl}, \mathrm{pH} 7.5,1 \mathrm{mM}$ EDTA, $10 \%$ dextran sulfate, $1 \times$ Denhardt's solution, $500 \mu \mathrm{g} / \mathrm{mL}$ polyA, $150 \mu \mathrm{g} / \mathrm{mL}$ yeast tRNA, and $70 \mathrm{mM}$ DTT for $16 \mathrm{hr}$ at $42^{\circ} \mathrm{C}$. Washing was performed in $4 \times \mathrm{SSC}, 5 \mathrm{mM}$ DTT at room temperature, followed by treatment with $20 \mu \mathrm{g} / \mathrm{mL}$ RNase $A$ in $0.5 \mathrm{M}$ $\mathrm{NaCl}, 5 \mathrm{mM}$ EDTA, $10 \mathrm{mM}$ Tris- $\mathrm{HCl}$, pH 7.5, at $37^{\circ} \mathrm{C}$ for $30 \mathrm{~min}$, and washed in the same buffer with $5 \mathrm{mM}$ DTT at $37^{\circ} \mathrm{C}$ for 30 $\mathrm{min}$. The final wash was twice $2 \times \mathrm{SSC}, 1 \mathrm{mM}$ DTT at room temperature (RT). Sections were dehydrated in $70 \%$ and $90 \%$ ethanol (each with $300 \mathrm{mM}$ ammonium acetate) and $100 \%$ ethanol and air dried. Slides were coated with Kodak NBT2 nuclear emulsion diluted with an equal volume $600 \mathrm{mM}$ ammonium acetate and exposed for 1 week to 4 weeks at $4^{\circ} \mathrm{C}$. They were developed in a Kodak D19 developer for $3 \mathrm{~min}$ and fixed in Kodak fix. Sections were stained with $0.025 \%$ toluidine blue $O$ for 5 min and mounted with D.P.X. Sections were photographed with a Nikon microscope equipped with dark-field and epipolarization optics.

\section{Primer Extension Analysis and RNA Sequencing}

Synthetic oligomers complementary to nucleotides 118 to 138 of the pPSENOD5 insert, nucleotides 51 to 71 of the pPSENOD3 insert, and nucleotides 57 to 77 of the pPsENOD14 insert were ${ }^{32}$ P-labeled using T4 polynucleotide kinase (Pharmacia-LKB Biotechnology Inc.). These primers $\left(1 \times 10^{6} \mathrm{cpm}\right)$ were coprecipitated with $20 \mu \mathrm{g}$ of total RNA. Nucleic acids were resuspended in 6.25 $\mu \mathrm{L}$ of annealing buffer $(50 \mathrm{mM}$ Tris- $\mathrm{HCl}, \mathrm{pH} 8.2,60 \mathrm{mM} \mathrm{NaCl}, 10$ $\mathrm{mM}$ DTT), put at $68^{\circ} \mathrm{C}$, and allowed to cool down to $35^{\circ} \mathrm{C}$. RT buffer $(2.25 \mu \mathrm{L})(250 \mathrm{mM}$ Tris- $\mathrm{HCl}, \mathrm{pH} 8.2,30 \mathrm{mM} \mathrm{MgCl}, 500$ $\mathrm{mM} \mathrm{NaCl}, 50 \mathrm{mM} \mathrm{DTT}), 2.5 \mu \mathrm{L}$ of deoxynucleotide triphosphate (dNTP) mixture (2 mM), and $0.5 \mu \mathrm{L}$ of avian myeloblastosis virus (AMV) reverse transcriptase (Life Science, St. Petersburg, FL, 25 units $/ \mu \mathrm{L}$ ) were added, and primer extension was performed at $45^{\circ} \mathrm{C}$ for $20 \mathrm{~min}$. Subsequently, $1 \mu \mathrm{L}$ of RNase A was added, and incubation was prolonged for $15 \mathrm{~min}$. The mixture was extracted once with phenol/chloroform (1:1) and ethanol precipitated using $2 \mu \mathrm{g} / \mathrm{mL}$ tRNA as a carrier. Upon resuspension in $1.5 \mu \mathrm{L}$ of $\mathrm{H}_{2} \mathrm{O}$, loading buffer was added, and after denaturation samples were analyzed on a $6 \%$ polyacrylamide/ $8 \mathrm{M}$ urea sequencing gel. For RNA sequencing $5 \times 10^{6} \mathrm{cpm}$ primer was coprecipitated with 80 $\mu \mathrm{g}$ of total RNA. The precipitate was resuspended in $12.5 \mu \mathrm{L}$ of annealing buffer and annealed as described above. RT buffer ( 4.5 $\mu \mathrm{L}$ ), $5 \mu \mathrm{L}$ of dNTP mixture ( $2 \mathrm{mM}$ ), and 25 units of AMV (RT) were added. Four microliters of this solution was added to four separate tubes containing $1 \mu \mathrm{L}$ of one of the four dideoxy-NTPs $(800 \mu \mathrm{M})$. Extension was performed for $20 \mathrm{~min}$ at $45^{\circ} \mathrm{C}$. Subsequently, 1 $\mu \mathrm{L}$ of the dNTP mixture was added for a chase reaction for 15 min at $45^{\circ} \mathrm{C}$. Samples were extracted, precipitated, and subjected to gel analysis as described above.

\section{ACKNOWLEDGMENTS}

We thank Drs. Scott Tigney and Gloria Coruzzi for providing the nodule cDNA library, Peter van Druten for photography, Piet Madern for artwork, Piet de Kam for growing plants, and Sacco de Vries for formatting sequence data. B.S. was supported by a grant from the Netherlands Organization for the Advancement of Scientific Research (NWO).

Received March 6, 1990; revised May 21, 1990.

\section{REFERENCES}

Berg, J.M. (1986). Potential metabolic binding domains in nucleic acid binding proteins. Science 232, 485-487.

Bisseling, T., van den Bos, R.C., and van Kammen, A. (1978). The effect of ammonium nitrate on the synthesis of nitrogenase and the concentration of leghemoglobin in pea root nodules induced by Rhizobium leguminosarum. Biochim. Biophys. Acta $539,1-11$

Cassab, G.J. (1986). Arabinogalactan proteins during the development of soybean root nodules. Planta 168, 441-446.

Cox, K.H., and Goldberg, R.B. (1988). Analysis of plant gene expression. In Plant Molecular Biology: A Practical Approach, C.H. Shaw, ed (Oxford, England: IRL Press), pp. 1-34.

De Maagd, R.A., Rao, A.S., Mulders, I.H.M., Goossen-de Roo, L., van Loosdrecht, M.C.M., Wijffelman, C.A., and Lugtenberg, B.J.J. (1989). Isolation and characterization of mutants of $R$. leguminosarum bv. Vicia strain 248 with altered lipopolysaccharides: Possible role of surface charge or hydrophobicity in bacterial release from the infection thread. J. Bacteriol. 171, 1143-1150.

De Vries, S.C., Springer, J., and Wessels, J.H.G. (1982). Diversity of abundant mRNA sequences and patterns of protein synthesis in etiolated and greened pea seedlings. Planta 156, 129-135.

Dickstein, R., Bisseling, T., Reinhold, V.N., and Ausubel, F.M. (1988). Expression of nodule-specific genes in alfalfa root nodules blocked at an early stage of development. Genes Dev. 2, 677-687.

Fincher, G.B., Stone, B.A., and Clarke, A.E. (1983). Arabinogalactan proteins: Structure, biosynthesis, and function. Annu. Rev. Plant Physiol. 34, 47-70.

Franssen, H.J., Nap, J.P., Gloudemans, T., Stiekema, W., van 
Dam, H., Govers, F., Louwerse, J., van Kammen, A., and Bisseling, T. (1987). Characterization of CDNA for nodulin-75 of soybean: A gene product involved in early stages of root nodule development. Proc. Natl. Acad. Sci. USA 84, 4495-4499.

Franssen, H.J., Scheres, B., van de Wiel, C., and Bisseling, T. (1988). Characterization of soybean (hydroxy)proline-rich early nodulins. In Molecular Genetics of Plant-Microbe Interactions, R. Palacios and D.P. Verma, eds (St. Paul: American Phytopathological Society Press), pp. 321-326.

Gloudemans, T., De Vries, S.C., Bussink, H.-J., Malik, N.S.A., Franssen, H.J., Louwerse, J., and Bisseling, T. (1987). Nodulin gene expression during soybean (Glycine max) nodule development. Plant Mol. Biol. 8, 395-403.

Govers, F., Gloudemans, T., Moerman, M., van Kammen, A., and Bisseling, T. (1985). Expression of plant genes during the development of pea nodules. EMBO J. 4, 861-867.

Govers, F., Nap, J.P., van Kammen, A., and Bisseling, T. (1987). CDNA cloning and developmental expression of pea nodulin genes. Plant Mol. Biol. 8, 425-435.

Jacobs, F.A., Zhang, M., Fortin, M.G., and Verma, D.P.S. (1987). Several nodulins of soybean share structural domains but differ in their subcellular locations. Nucl. Acids Res. 15, 1271-1280.

Knox, J.P., Day, S., and Roberts, K. (1989). A set of cell surface glycoproteins from an early marker of cell position but not cell type in the root apical meristem of Daucus carota L. Development 106, 47-56.

Korneluk, R.G., Quan, F., and Gravel, R.A. (1985). Rapid and reliable dideoxy sequencing of double-stranded DNA. Gene $\mathbf{4 0}$, 317-323.

Ljones, T. (1974). The enzyme system. In Biology of Nitrogen Fixation, A. Quispel, ed (Amsterdam: North-Holland Publishing Company), pp. 617-639.

Lütcke, H.A., Chow, K.C., Mickel, F.S., Moss, K.A., Kern, H.F., and Scheele, G.A. (1987). Selection of AUG initiation codons differs in plants and animals. EMBO J. 6, 43-48.

Maniatis, T., Fritsch, E.F., and Sambrook, J. (1982). Molecular Cloning: A Laboratory Manual. (Cold Spring Harbor, NY: Cold Spring Harbor Laboratory).
Newcomb, W. (1976). A correlated light and electron microscopic study of symbiotic growth and differentiation in Pisum sativum root nodules. Can. J. Bot. 54, 2163-2186.

Rigaud, G., Grange, T., and Pictet, R. (1987). The use of $\mathrm{NaOH}$ as transfer solution onto nylon membrane decreases the hybridization efficiency. Nucl. Acids Res. 15, 857.

Rogers, S.O., and Bendich, A.J. (1988). Extraction of DNA from plant tissues. In Plant Molecular Biology Manual, S.B. Gelbin and R.A. Schilperoort, eds (Dordrecht, The Netherlands: Kluwer Academic Publishers), pp. 1-10.

Sandal, N.N., Bojsen, K., and Marcker, K.A. (1987). A small family of nodule specific genes from soybean. Nucl. Acids Res. 15, 1507-1519.

Scheres, B., van de Wiel, C., Zalensky, A., Horvath, B., Spaink, H., van Eck, H., Zwartkruis, F., Wolters, A., Gloudemans, T., van Kammen, A., and Bisseling, T. (1990). The ENOD12 gene product is involved in the infection process during the peaRhizobium interaction. Cell 60, 281-294.

Tigney, S.V., Walker, E.L., and Coruzzi, G.M. (1987). Glutamine synthetase genes of pea encode distinct polypeptides which are differentially expressed in leaves, roots and nodules. EMBO J. 6, 1-9.

van de Wiel, C., Scheres, B., Franssen, H.J., van Lierop, M., van Lammeren, A., van Kammen, A., and Bisseling, T. (1990). The early nodulin transcript ENOD2 is located in the nodule parenchyma (inner cortex) of pea and soybean root nodules. EMBO J. 9, 1-8.

van Holst, G.-J., Klis, F.M., De Wildt, P.J.M., Hazenberg, C.A.M., Buijs, J., and Stegwee, D. (1981). Arabinogalactan protein from a crude cell organelle fraction of Phaseolus vulgaris $L$. Plant Physiol. 68, 910-913.

van Kammen, A. (1984). Suggested nomenclature for plant genes involved in nodulation and symbiosis. Plant Mol. Biol. Rep. 2, 43-45.

Vincent, J.M. (1980). Factors controlling the legume-Rhizobium symbiosis. In Nitrogen Fixation II, W.E. Newton, and W.H. Orme-Johnson, eds (Baltimore: University Park Press), pp. 103-109.

Von Heijne, G. (1983). Patterns of amino acids near signalsequence cleavage sites. Eur. J. Biochem. 133, 17-21. 